\title{
Heparin and Carboxymethylchitosan Metal Nanoparticles: An Evaluation of Their Cytotoxicity
}

\author{
Adriana Bava, ${ }^{1}$ Francesca Cappellini, ${ }^{1}$ Elisa Pedretti, ${ }^{1}$ \\ Federica Rossi, ${ }^{1}$ Enrico Caruso, ${ }^{2}$ Elena Vismara, ${ }^{3,4}$ Maurizio Chiriva-Internati, ${ }^{5}$ \\ Giovanni Bernardini, ${ }^{1,4}$ and Rosalba Gornati ${ }^{1,4}$ \\ ${ }^{1}$ Dipartimento di Biotecnologie e Scienze della Vita, Università dell'Insubria, 21100 Varese, Italy \\ ${ }^{2}$ Dipartimento di Scienze Teoriche ed Applicate, Università dell'Insubria, 21100 Varese, Italy \\ ${ }^{3}$ Dipartimento di Chimica, Materiali e Ingegneria Chimica "G. Natta," Politecnico di Milano, 20131 Milano, Italy \\ ${ }^{4}$ Interuniversity Center "The Protein Factory," Politecnico di Milano, ICRM-CNR Milano and Università dell'Insubria, \\ 20131 Milano, Italy \\ ${ }^{5}$ Division of Oncology and Hematology, Texas Tech University Health Sciences Center, Lubbock, TX 79409, USA
}

Correspondence should be addressed to Rosalba Gornati; rosalba.gornati@uninsubria.it

Received 23 October 2012; Revised 3 January 2013; Accepted 3 January 2013

Academic Editor: Xudong Huang

Copyright (c) 2013 Adriana Bava et al. This is an open access article distributed under the Creative Commons Attribution License, which permits unrestricted use, distribution, and reproduction in any medium, provided the original work is properly cited.

In the search for noninvasive diagnostic techniques and new therapies, "nanosystems", which are capable of binding and targeting bioactive molecules, are becoming increasingly important. In this context, biocompatible coatings are gaining interest, not only for their biological effects but also because they are considered capable to mask nanoparticle toxicity. In this work, we have compared the toxicity of nanoparticles coated with heparin and carboxymethylchitosan in the SKOV-3 cell line. Our results indicate that heparin and carboxymethylchitosan coatings do not guarantee the decrease of nanoparticle intrinsic toxicity which is often envisaged. Nonetheless, these coatings provide the opportunity for further functionalization with a variety of biomolecules for their use in theranostics.

\section{Introduction}

Nanomedicine, the application of nanotechnology in healthcare, offers numerous and promising possibilities to significantly improve medical diagnosis and therapy. New sensitive diagnostic devices, in fact, will permit very early personal risk assessment, and the abatement of costs for the disease treatment is a must for healthcare. Due to its high potential, nanomedicine holds the promise to greatly improve the efficacy of pharmaceutical therapy, reduce side effects, and make drug administration more convenient [1].

In this context, nanoparticles (NPs), particularly magnetic nanoparticles (MNPs), coated with biodegradable polymers, are attracting widespread attention for targeted therapy and imaging. These coatings can stabilize the NP systems also in hydrophilic fluids, minimize opsonization by the mononuclear phagocytic system, and prolong blood circulation [2-7]. Furthermore, this surface layer can be functionalized with a variety of biological moieties for tumor-specific targeting [8$10]$.

Among the biological molecules used for NP coating, chitosan, particularly carboxymethylchitosan (CMCS), and heparin appear very interesting also because they are considered capable to mask NP toxicity $[11,12]$. We should not, in fact, oversee the toxicity of cobalt and nickel oxide NPs [1316] nor their potential effect on the environment [17]. Even though heparin is predominantly used as anticoagulant, its ability to interact with proteins makes it very attractive. NPs coated with heparin (NP@heparin) are extensively studied because of their several biomedical applications ranging from tissue engineering to biosensors passing for its use in cancer therapy [3]. As well as heparin, also chitosan NPs have demonstrated anticancer activity in vitro as well as in vivo even though the mechanisms remain to be elucidated [18].

In this paper, we have reported cytotoxicity and uptake of some transition metal oxide NPs $\left(\mathrm{Co}_{3} \mathrm{O}_{4}, \mathrm{Fe}_{3} \mathrm{O}_{4}\right.$, and 


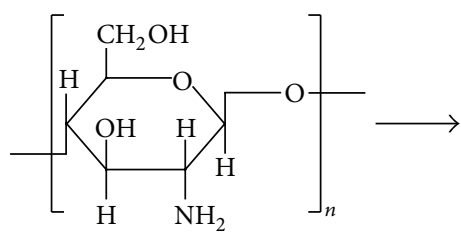

(A)

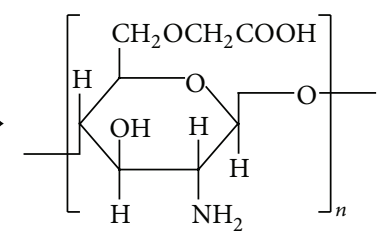

(B)
FIGURE 1: Chemical structure of chitosan (A) and carboxymethylchitosan (B).

$\mathrm{NiO})$ coated with heparin and of $\mathrm{Fe}_{3} \mathrm{O}_{4} \mathrm{NPs}$ coated with CMCS $\left(\mathrm{Fe}_{3} \mathrm{O}_{4} @\right.$ CMCS) in SKOV-3 cell. Transition metal NPs are especially used to enhance surface electrochemical reactivity to further improve the performance of lithium-ion batteries [19] as well as in catalysis [20, 21]. Nevertheless, the therapeutic use of transition metal conjugates was already known in the sixteenth century because of their different oxidation states and ability to interact with negatively charged molecules forming chelation complexes [22].

The results here reported indicate that heparin and CMCS alone did not show any cytotoxicity effect at the concentration used in the experiments. Unfortunately, they did not seem to be able to drastically reduce NP toxicity.

\section{Materials and Methods}

2.1. Chemicals. Iron oxide $\left(\mathrm{Fe}_{3} \mathrm{O}_{4}\right)$, cobalt oxide $\left(\mathrm{Co}_{3} \mathrm{O}_{4}\right)$ and nickel oxide (NiO) NPs ( $<50 \mathrm{~nm}$ particle size), chitosan powder (75\% degree of acetylation), monochloroacetic acid, 1-ethyl-3-(3-dimethylaminopropyl)carbodiimide hydrochloride $(\mathrm{EDC} \cdot \mathrm{HCl})$, and $\mathrm{N}$-hydroxysuccinimide (NHS) were purchased from Sigma-Aldrich, Milan, Italy. Heparin, in the form of sodium salt, was kindly provided by LDO Company, Trino Vercellese, Italy. CellTiter-Glo Luminescent Cell Viability Assay was purchased from Promega, Milan, Italy. Isopropanol was purchased from J.T.Baker, Milan, Italy. All other reagents, analytical or cell culture grade, were purchased from Sigma-Aldrich, Milan, Italy. The Milli-Q ultrapure water was used.

2.2. Nanoparticles Characterization. The particle size distribution was studied by transmission electron microscopy (TEM) using a $90 \mathrm{keV}$ JEOL-1010 electron microscope (Tokyo, Japan). TEM samples were prepared by placing $10 \mu \mathrm{L}$ of a dilute suspension of $\mathrm{Fe}_{3} \mathrm{O}_{4}$ nanoparticles in ethanol on a carbon-coated copper grid and allowing the solvent to evaporate at room temperature. The average particle size $\left(D_{\text {TEM }}\right)$ and distribution were evaluated by measuring the largest internal dimension of 100 particles.

2.3. Synthesis of Carboxymethylchitosan (CMCS). CMCS was prepared as reported by Zhu et al. [23]. The chemical structures of chitosan and CMCS are reported in Figure 1.

\subsection{Coating of Metal Nanoparticles}

2.4.1. NP@heparin. A suspension of $\mathrm{NPs}\left(\mathrm{Co}_{3} \mathrm{O}_{4}\right.$ or $\mathrm{Fe}_{3} \mathrm{O}_{4}$ or $\mathrm{NiO})$ in distilled water $(100 \mathrm{mg} / 5 \mathrm{~mL})$ obtained by ultrasonication for $5 \mathrm{~min}$ (Sonica 5300MH-Soltec) was transferred into a solution of heparin, $(1.045 \mathrm{~g} / 25 \mathrm{~mL}, \mathrm{pH} 7$ adjusted with $0.01 \mathrm{~N} \mathrm{NaOH})$. The mixture was stirred overnight (130 rpm, $25^{\circ} \mathrm{C}$, Julabo SW22). $\mathrm{Co}_{3} \mathrm{O}_{4} @$ heparin and $\mathrm{NiO} @$ heparin were separated by centrifugation $(1 \mathrm{~h}, 6300 \times \mathrm{g}$, Hettich Zentrifugen-Rotina $35 \mathrm{~F}$ ), while $\mathrm{Fe}_{3} \mathrm{O}_{4} @$ heparin was separated by a neodymium magnet ( $\mathrm{NdFeB}$ Nickel plated, magnetization N45). NP@heparin were collected in diethyl ether, recovered after solvent elimination and dried at $50^{\circ} \mathrm{C}$ for $1 \mathrm{~h}$.

2.4.2. $\mathrm{Fe}_{3} \mathrm{O}_{4} @ C M C S$ Electrostatic Bound. A suspension of $100 \mathrm{mg}$ of $\mathrm{Fe}_{3} \mathrm{O}_{4} \mathrm{NPs}$ in $5 \mathrm{~mL}$ water was prepared by ultrasonic bath for $10 \mathrm{~min}$. Separately, $100 \mathrm{mg}$ of CMCS was dissolved in $20 \mathrm{~mL}$ of water using a magnetic stirrer until complete dissolution, then added to the $\mathrm{Fe}_{3} \mathrm{O}_{4}$ NPs dispersion and mixed by ultrasonic bath at $0^{\circ} \mathrm{C}$ for $1 \mathrm{~h}$. After reaction, the $\mathrm{Fe}_{3} \mathrm{O}_{4} @ \mathrm{CMCS}$ was separated from unbound CMCS by a neodymium magnet, washed several times with water, and centrifuged at $15000 \times \mathrm{g}, 20 \mathrm{~min}$. The pellet was resuspended in ethyl alcohol then, after anhydrification, $\mathrm{Fe}_{3} \mathrm{O}_{4} @ \mathrm{CMCS}$ was dried overnight at $50^{\circ} \mathrm{C}$.

2.4.3. $\mathrm{Fe}_{3} \mathrm{O}_{4} @ \mathrm{CMCS}$-Covalent Bound. The covalent immobilization of CMCS on $\mathrm{Fe}_{3} \mathrm{O}_{4}$ NPs was conducted following Liang and Zhang method [24] with some modifications. Briefly, $75 \mathrm{mg}$ of $\mathrm{Fe}_{3} \mathrm{O}_{4} \mathrm{NPs}$ were added to $4 \mathrm{~mL}$ of sodium phosphate buffer $(200 \mathrm{mM}, \mathrm{pH}$ 5) containing $25 \mathrm{mg}$ of $\mathrm{EDC} \cdot \mathrm{HCl}$ and $20 \mathrm{mg}$ of NHS; the mixture was left in an ultrasonic bath for $30 \mathrm{~min}$. The $\mathrm{Fe}_{3} \mathrm{O}_{4} \mathrm{NPs}$ activated were separated from excess of reagents by magnetic decantation, then resuspended in $3 \mathrm{~mL}$ of $200 \mathrm{mM}$ sodium phosphate buffer $(\mathrm{pH} 7)$ by sonication for $10 \mathrm{~min} .1 \mathrm{~mL}$ of CMCS solution $(25 \mathrm{mg} / \mathrm{mL}$ in $200 \mathrm{mM}$ sodium phosphate buffer, $\mathrm{pH}$ 7) was added to the suspension of the NPs and the reaction mixture was sonicated for $3 \mathrm{~h}$. Finally, the $\mathrm{Fe}_{3} \mathrm{O}_{4} @$ CMCS was recovered by magnet, washed with water, and dried overnight at $50^{\circ} \mathrm{C}$.

2.4.4. Determination of Unbound Fe. $5 \mathrm{mg}$ of $\mathrm{Fe}_{3} \mathrm{O}_{4} \mathrm{NPs}$, or $\mathrm{Fe}_{3} \mathrm{O}_{4} @$ heparin, or $\mathrm{Fe}_{3} \mathrm{O}_{4} @ \mathrm{CMCS}$ electrostatically bound or $\mathrm{Fe}_{3} \mathrm{O}_{4} @ \mathrm{CMCS}$ covalently bound were resuspended in $5 \mathrm{~mL}$ of $\mathrm{H}_{2} \mathrm{O}$, sonicated for $20 \mathrm{~min}$, and left at $37^{\circ} \mathrm{C}$ for $72 \mathrm{~h}$. Afterwards, NP systems were separated from the supernatant by a neodymium magnet, centrifuged twice at $15000 \times \mathrm{g}$ for $15 \mathrm{~min}$ at $4^{\circ} \mathrm{C}$, then ultracentrifuged at $300000 \times \mathrm{g}$ for $2 \mathrm{~h}$ at $4^{\circ} \mathrm{C}$. After centrifugation, supernatants were filtered using a $0.22 \mu \mathrm{m}$ pore size membrane. The amount of $\mathrm{Fe}$ (II), eventually released in solution, was determined by complexometric analysis with the $o$-phenanthroline [25]. The $\mathrm{Fe}$ (II), in the presence of $o$-phenanthroline, form the stable red-orange complex $\left[\left(\mathrm{C}_{12} \mathrm{H}_{18} \mathrm{~N}_{2}\right)_{3} \mathrm{Fe}\right]^{2+}$. The intensity of the color does not vary in the range of $\mathrm{pH}$ between 3 and 9. The maximum absorption wavelength occurs at $510 \mathrm{~nm}$. The possible Fe (III) is reduced to Fe (II) by treatment with hydroxylamine hydrochloride.

2.5. FT-IR Spectra Analysis. Characterization of the samples was performed using the solid phase Fourier transform infrared spectroscopy (FT-IR). Spectra were obtained using a 
Nicolet, Avatar 360. Samples were mixed with infrared grade $\mathrm{KBr}$ in a proportion of $2: 100(\mathrm{w} / \mathrm{w})$.

2.6. Cell Culture. SKOV-3 cell line was maintained as adherent cells in RPMI 1640 medium, at $37^{\circ} \mathrm{C}$ in a humidified 5\% $\mathrm{CO}_{2}$ atmosphere. Medium was supplemented with $10 \%$ fetal bovine serum and $2 \mathrm{mM} \mathrm{L}$-glutamine. Cells were passaged as needed using 0.5\% trypsin EDTA.

2.7. Cell Viability. Cell viability was determined measuring ATP content by the CellTiter-Glo Assay according to the manufacturer's instructions. In details, $200 \mu \mathrm{L}$ of cell suspension (containing $2 \times 10^{4}, 1 \times 10^{4}, 5 \times 10^{3}, 25 \times 10^{2}$ cells depending of the exposure time) were seeded into 96 -well assay plates and cultivated for $24 \mathrm{~h}$ at $37^{\circ} \mathrm{C}$ in $5 \% \mathrm{CO}_{2}$ to equilibrate and become attached prior to the treatment. Then, cells were exposed to $100 \mu \mathrm{L}$ of increasing concentrations of heparin, NP@heparin, CMCS, $\mathrm{Fe}_{3} \mathrm{O}_{4} @ \mathrm{CMCS}$ electrostatic, and $\mathrm{Fe}_{3} \mathrm{O}_{4} @ \mathrm{CMCS}$ covalent for 0.5, 1, 2, 24, 48, and $72 \mathrm{~h}$. After the treatment, plates were equilibrated for $30 \mathrm{~min}$ at room temperature and then $100 \mu \mathrm{L}$ of CellTiter-Glo reagent was added to each well. Plates were shaken for $2 \mathrm{~min}$ and left at room temperature for $10 \mathrm{~min}$ prior recording luminescent signals using the Infinite F200 plate reader (Tecan Group, Switzerland). Cell viability, expressed as ATP content and normalized against control values, was recorded. All the experiments were performed in triplicate.

2.8. Cellular Uptake. $10^{4}$ cells were seeded on a coverslip $(12 \mathrm{~mm} \varnothing)$ into 12 -well assay plate and cultivated for $24 \mathrm{~h}$ at $37^{\circ} \mathrm{C}$ in $5 \% \mathrm{CO}_{2}$ to equilibrate and become attached before treatment. Cells were then incubated for 4 or $24 \mathrm{~h}$ with 25, 50, and $100 \mu \mathrm{g} / \mathrm{mL} \mathrm{Fe}_{3} \mathrm{O}_{4} @$ heparin, $\mathrm{Fe}_{3} \mathrm{O}_{4} @ \mathrm{CMCS}$ electrostatic, and $\mathrm{Fe}_{3} \mathrm{O}_{4} @ \mathrm{CMCS}$ covalent and visualized by Prussian blue staining for iron detection. For this microscopic technique, the cells were fixed in ice-cold ethanol for $5 \mathrm{~min}$, stained with an equal volume of $2 \%$ hydrochloric acid and $2 \%$ potassium ferrocyanide trihydrate for $15 \mathrm{~min}$, and counterstained with $0.5 \%$ neutral red for $3 \mathrm{~min}$. The preparations were then washed with distilled water and dried by increasing concentrations of ethanol, than mounted in DePeX (Serva, Germany). Observations were performed by a Zeiss Axiophot microscope under bright light illumination and photographs were acquired by a Zeiss AxioCam ERc5s camera.

Furthermore, for TEM studies, $10^{6}$ cells, seeded in a $10 \mathrm{~cm}$ Petri dish, are exposed to $40 \mu \mathrm{g} / \mathrm{mL}$ of NP@heparin, $\mathrm{Fe}_{3} \mathrm{O}_{4} @ \mathrm{CMCS}$ electrostatic, and $\mathrm{Fe}_{3} \mathrm{O}_{4} @ \mathrm{CMCS}$ covalent, for $30 \mathrm{~min}$ or $3 \mathrm{~h}$. Then cells were harvested, fixed in $2 \%$ glutaraldehyde in $0.1 \mathrm{M}$ sodium cacodylate buffer $(\mathrm{pH}$ 7.2) for $10 \mathrm{~min}$ on ice and for $30 \mathrm{~min}$ at room temperature, washed in the same buffer, and postfixed in dark for $1 \mathrm{~h}$ with $1 \%$ osmium tetroxide in $0.1 \mathrm{M}$ sodium-cacodylate buffer ( $\mathrm{pH}$ 7.2) at room temperature. After dehydration standard steps with a series ethyl alcohol, samples were embedded in an Epon-Araldite 812 1:1 mixture. Thin sections $(90 \mathrm{~nm})$, obtained with a ReichertUltracut S Ultratome (Leica, Nussloch, Germany), were stained with uranyl acetate and lead citrate according to the standard methods and observed with a Jeol 1010 electron microscope (Jeol, Tokyo, Japan) operated at $90 \mathrm{keV}$.

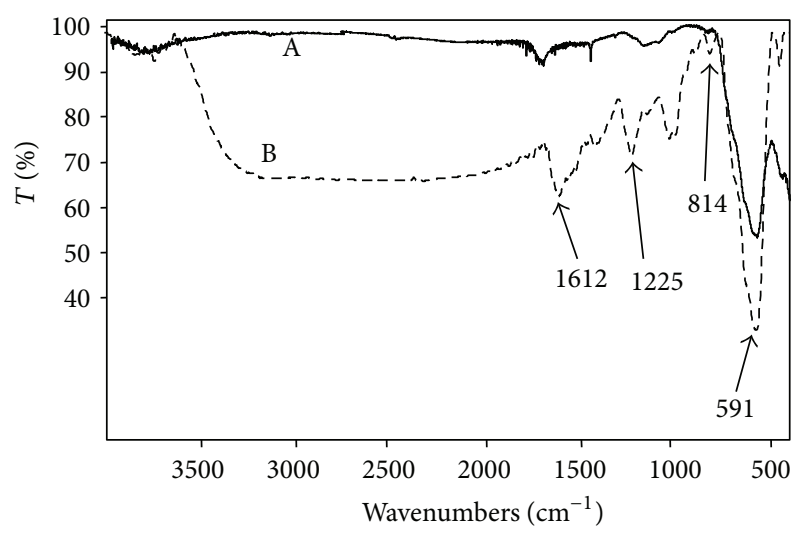

FIgURE 2: FT-IR spectra of $\mathrm{Fe}_{3} \mathrm{O}_{4} \mathrm{NPs}(\mathrm{A})$ and $\mathrm{Fe}_{3} \mathrm{O}_{4} @$ heparin (B). The peaks at $814 \mathrm{~cm}^{-1}$, between 1000 and $1400 \mathrm{~cm}^{-1}$ and those at 1225 , and $1612 \mathrm{~cm}^{-1}$ are indicative of the heparin coating.

2.9. Statistical Analysis. Cell viability values were expressed as mean \pm standard error (SE). Analysis of variance (two-way ANOVA), for balanced mixed-effect experiments (uncoated NPs, coated NPs, and exposure times), was performed using KaleidaGraph 4.0 (Synergy Software). Statistical significant differences were fixed at $P \leq 0.05\left(^{*}\right), P \leq 0.01\left(^{* *}\right)$, and $P \leq 0.005\left(^{* * *}\right)$.

\section{Results}

3.1. Nanoparticles Characterization. To confirm the characteristics reported on the product label by Sigma-Aldrich, we have measured $\mathrm{Fe}_{3} \mathrm{O}_{4}$ NPs diameter. $D_{\text {TEM }}$ was $25.08 \mathrm{~nm}$ $\pm \mathrm{SD}$ 4.09. The amount of $\mathrm{Fe}$ released from $\mathrm{Fe}_{3} \mathrm{O}_{4} \mathrm{NPs}$, or $\mathrm{Fe}_{3} \mathrm{O}_{4} @$ heparin, or $\mathrm{Fe}_{3} \mathrm{O}_{4} @$ CMCS-electrostatic bound or $\mathrm{Fe}_{3} \mathrm{O}_{4} @ \mathrm{CMCS}$-covalent bound, in our experimental conditions, was under the limit of detection of the method (0.02 ppm).

3.2. FT-IR Spectra Analysis. In Figure 2, we have reported, as example, the FT-IR spectra of $\mathrm{Fe}_{3} \mathrm{O}_{4} \mathrm{NPs}$ (A) and $\mathrm{Fe}_{3} \mathrm{O}_{4} @$ heparin (B). Spectrum (B) shows, at $591 \mathrm{~cm}^{-1}$, the characteristic peak of $\mathrm{Fe}-\mathrm{O}$ stretch, while, between 1000 and $1400 \mathrm{~cm}^{-1}$, peaks associated to $\mathrm{C}-\mathrm{O}$ and $\mathrm{C}-\mathrm{C}$ bonds due to the presence of heparin are present. Other peaks at 814, 1225, and $1612 \mathrm{~cm}^{-1}$ can be assigned to the stretching of $-\mathrm{C}-\mathrm{O}-\mathrm{S}$, $\mathrm{S}=\mathrm{O}$, and $-\mathrm{COO}^{-}$of the sulphates and carboxylate groups. Lambda shifts toward lower values compared to heparin alone are probably ascribable to the interaction with iron oxide.

FT-IR spectra of chitosan (A) and CMCS (B) are shown in Figure 3. Spectrum A shows the basic characteristic peaks of chitosan: $3550 \mathrm{~cm}^{-1}$ (O-H stretch), $2930 \mathrm{~cm}^{-1}$ (C-H stretch), $1648 \mathrm{~cm}^{-1}$ (NH bending), $1405 \mathrm{~cm}^{-1}$ (O-H bending), and $1080 \mathrm{~cm}^{-1}$ (C-O stretch). In addition to the peaks at 3550 , 2930, 1405, and $1080 \mathrm{~cm}^{-1}$, CMCS spectrum (B) reports an expanded and intense peak at $1612 \mathrm{~cm}^{-1}$ probably due to the overlapping of the signals of $\mathrm{NH}$ bending $\left(1648 \mathrm{~cm}^{-1}\right)$ and $\mathrm{COO}^{-}\left(1598 \mathrm{~cm}^{-1}\right)$ [23]. 


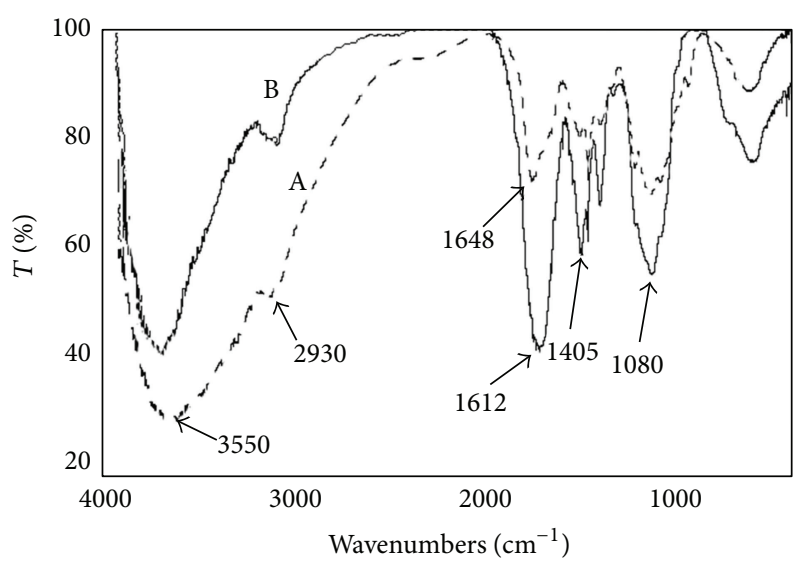

FIgUre 3: FT-IR spectra chitosan (A) and CMCS (B). Chemical modification of chitosan is confirmed by the presence of the intense peak at $1612 \mathrm{~cm}^{-1}$, attributed to the overlapping of the signals of $\mathrm{NH}$ bending and $-\mathrm{COO}^{-}$.

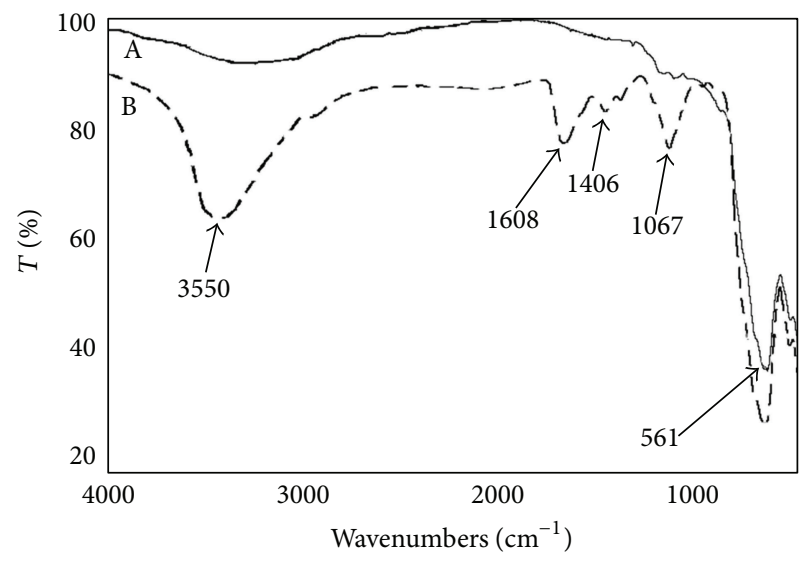

FIgUre 4: FT-IR spectra $\mathrm{Fe}_{3} \mathrm{O}_{4} \mathrm{NPs}(\mathrm{A})$ and $\mathrm{Fe}_{3} \mathrm{O}_{4} @ \mathrm{CMCS}$ (B). The peaks at $1067,1406,1608$, and $3550 \mathrm{~cm}^{-1}$ indicate the presence of CMCS on the $\mathrm{Fe}_{3} \mathrm{O}_{4} \mathrm{NPs}$ surface.

$\mathrm{Fe}_{3} \mathrm{O}_{4} \mathrm{NPs}(\mathrm{A})$ and $\mathrm{Fe}_{3} \mathrm{O}_{4} @$ CMCS (B) spectra are shown in Figure 4. In spectrum $A$, the peak at $561 \mathrm{~cm}^{-1}$ is that characteristic of $\mathrm{Fe}-\mathrm{O}$ stretch. Spectrum B, beside to the peak at $561 \mathrm{~cm}^{-1}$, reports the absorbance of CMCS molecule, in particular $1067 \mathrm{~cm}^{-1}(\mathrm{C}-\mathrm{O}$ stretch $), 1406 \mathrm{~cm}^{-1}(\mathrm{O}-\mathrm{H}$ bend), $1608 \mathrm{~cm}^{-1}$ (overlapping of the peaks of $\mathrm{NH}_{2}, \mathrm{COOH}$, and $\mathrm{COO}^{-}$), and $3550 \mathrm{~cm}^{-1}$ (O-H stretch). No significant differences were observed between spectra of $\mathrm{Fe}_{3} \mathrm{O}_{4} @ \mathrm{CMCS}$ electrostatically and covalently bound.

3.3. Cell Viability after NP@heparin Treatment. As reported in Figure 5(a), heparin alone was not toxic in the examined concentration range. A dose- and time-dependent reduction in cell viability was observed for all the examined NP systems, although $\mathrm{Fe}_{3} \mathrm{O}_{4} \mathrm{NPs}$ appear less toxic than $\mathrm{Co}_{3} \mathrm{O}_{4}$ NPs which is less toxic than NiO NPs, see Figures 6(a), 7(a), and 8(a).

Regarding the comparison between uncoated and coated NPs, our data indicate that the coating did not decrease the NPs toxicity. As demonstrated in Figure 6, $\mathrm{Co}_{3} \mathrm{O}_{4} \mathrm{NPs}$ were less toxic than $\mathrm{Co}_{3} \mathrm{O}_{4} @$ heparin for all the examined concentrations and time of treatment. The differences were less indicative for $\mathrm{Fe}_{3} \mathrm{O}_{4} \mathrm{NPs}$ and $\mathrm{NiO} \mathrm{NPs}$ (Figures 7 and 8). For further details, see Supplementary Material Tables 1, 2, and 3 available online at http://dx.doi.org/10.1155/2013/314091.

3.4. Cell Viability after $\mathrm{Fe}_{3} \mathrm{O}_{4} @ \mathrm{CMCS}$ Treatment. The ATP content of SKOV-3 treated with $\mathrm{Fe}_{3} \mathrm{O}_{4} \mathrm{NPs}, \mathrm{Fe}_{3} \mathrm{O}_{4} @$ CMCSelectrostatic, and $\mathrm{Fe}_{3} \mathrm{O}_{4} @ \mathrm{CMCS}$ covalent are displayed in Figure 9. The percentage of CMCS bound to NPs was less than $4 \%$ of the total weight; therefore, it was reasonable to compare the amount of coated and uncoated $\mathrm{Fe}_{3} \mathrm{O}_{4} \mathrm{NPs}$ neglecting the weight of CMCS bound. As previously reported (Figure 5(b)), CMCS itself did not show cytotoxicity at the tested concentrations. On the contrary, $\mathrm{Fe}_{3} \mathrm{O}_{4} @ \mathrm{CMCS}$ covalent, and electrostatic, caused a dose-dependent reduction of ATP (Figures 9(a), 9(b) and 9(c)) more pronounced compared to the bare $\mathrm{Fe}_{3} \mathrm{O}_{4} \mathrm{NPs}$. For further details see Supplementary Material Table 4.

3.5. Cellular Uptake. Figures 10(a)-10(d) show the uptake of coated $\mathrm{Fe}_{3} \mathrm{O}_{4} \mathrm{NPs}$ by using the classical Prussian blue method. The cytoplasm is full of NPs around the nucleus but never inside. $\mathrm{Fe}_{3} \mathrm{O}_{4} @$ heparin (Figure 10(d)) are more internalized compared to $\mathrm{Fe}_{3} \mathrm{O}_{4} @$ CMCS covalent (Figure 10(b)) and electrostatic (Figure 10(c)). Apparently, no differences are observed between the two chitosan systems. Coated $\mathrm{Fe}_{3} \mathrm{O}_{4} \mathrm{NPs}$ are readily incorporated into the cells already after $4 \mathrm{~h}$; therefore, it is not possible to assert a time and dose dependence. In addition, for all the NP systems, it is observed that internalized NP did not interfere with mitosis process (Figures 10(b)-10(d)).

TEM images (Figure 11) confirmed that NP@heparin are readily internalized; in fact, already after $30 \mathrm{~min}$ of incubation NPs appeared inside the cells. Once entered most of the NPs remained in the cytoplasm, free or inside vesicles (Figures 11(a)-11(c)). As already highlighted by optical microscope, besides being rapid, internalization of the nanoparticles was aspecific. In these pictures, NP@heparin are identified as high electron density objects since NPs maintained the morphology observed in cell-free environment (Figure 11(d)). Worth to note is that, also after $3 \mathrm{~h}$ of exposure, no NP@heparin was observed in the nuclei even though the massive internalization of NPs can modify nucleus shape (Figure 12).

From our observations, the internalization did not seem to be influenced by the coating. Our hypothesis is confirmed by TEM picture (Figure 13) that did not show appreciable differences in cellular localization between $\mathrm{Fe}_{3} \mathrm{O}_{4} @ \mathrm{CMCS}$ electrostatically or covalently bound and NP@heparin (Figures 11 and 12).

\section{Discussion}

In recent years, the use of NPs, particularly MNPs, has expanded into biomedical research. Due to their unique properties such as small size, large surface area, and high reactivity, they are particularly suitable for diagnosis and therapy [1, 26-29]. Often, NPs have to be covered with molecules to get a core@shell system capable to bind bioactive 


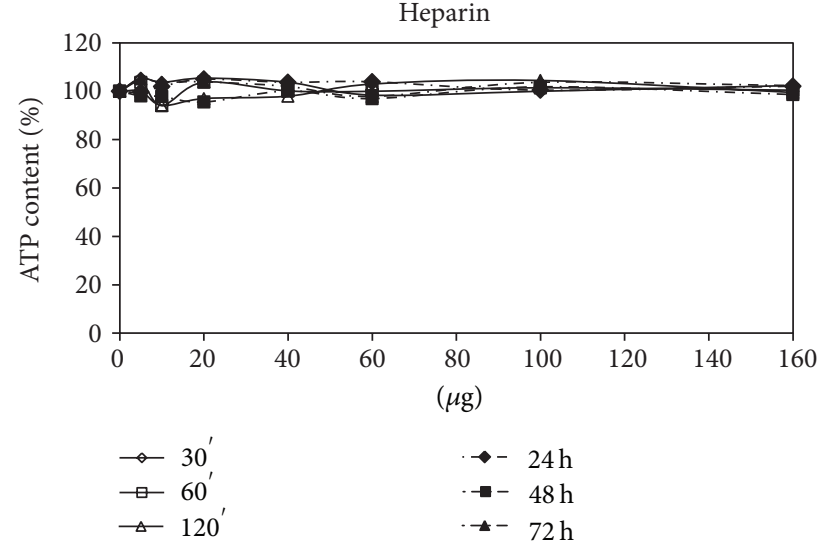

(a)

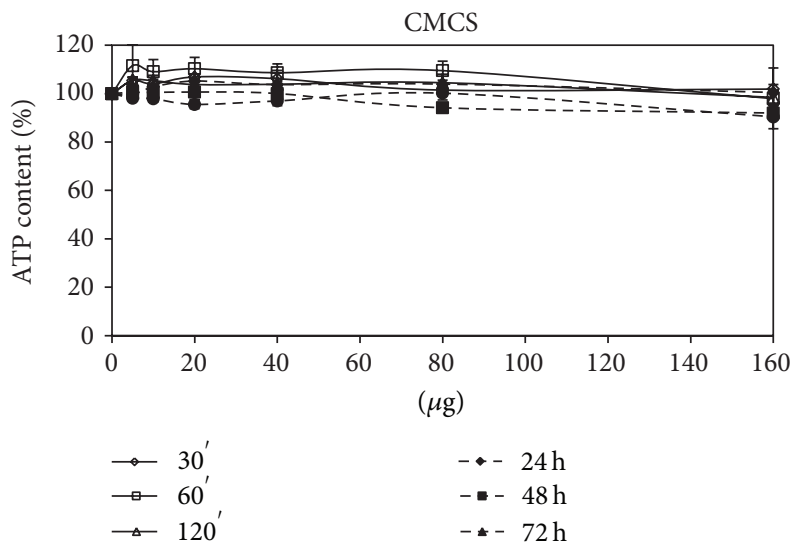

(b)

Figure 5: Percentage of ATP content, normalized to control, in SKOV-3 exposed to heparin (a) and carboxymethylchitosan (b) for different times.

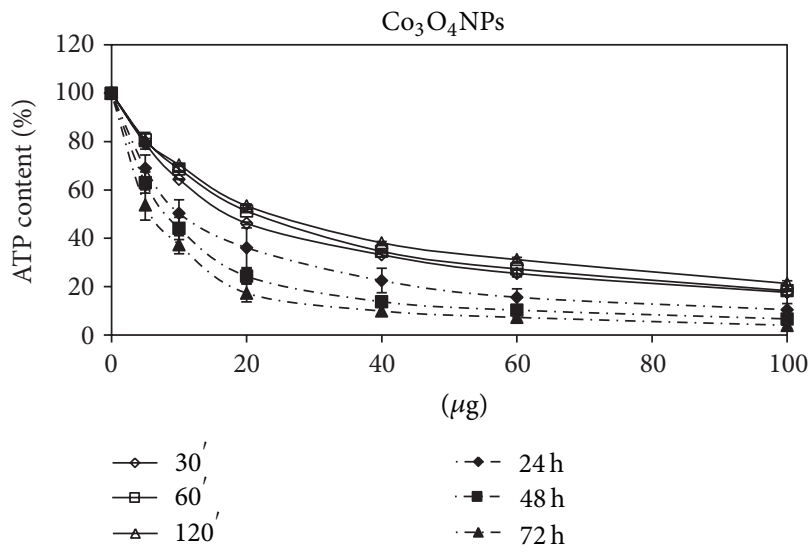

(a)

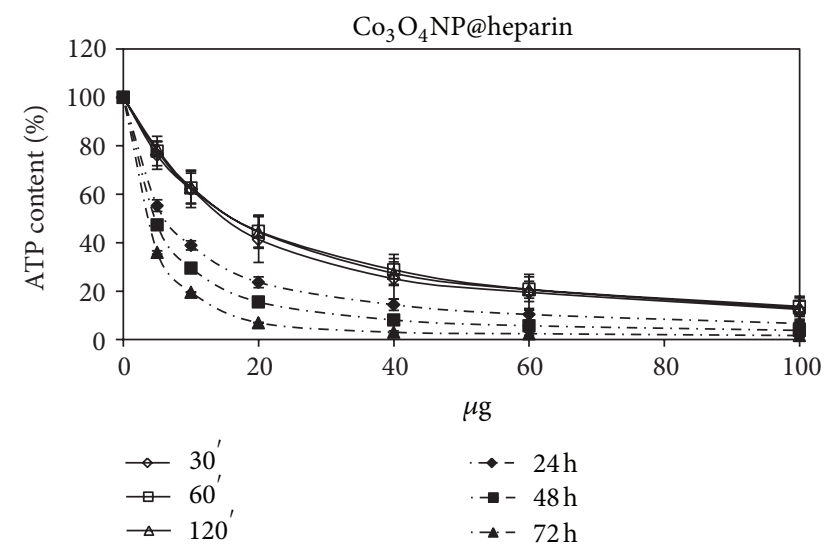

(b)

Figure 6: Percentage of ATP content, normalized to control, in SKOV-3 exposed to $\mathrm{Co}_{3} \mathrm{O}_{4} \mathrm{NPs}$ (a) and $\mathrm{Co}_{3} \mathrm{O}_{4} @$ heparin (b) for different times.

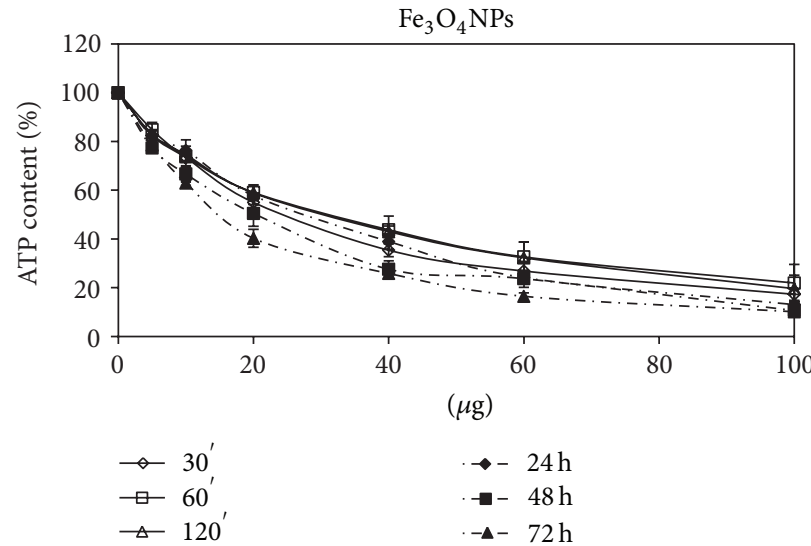

(a)

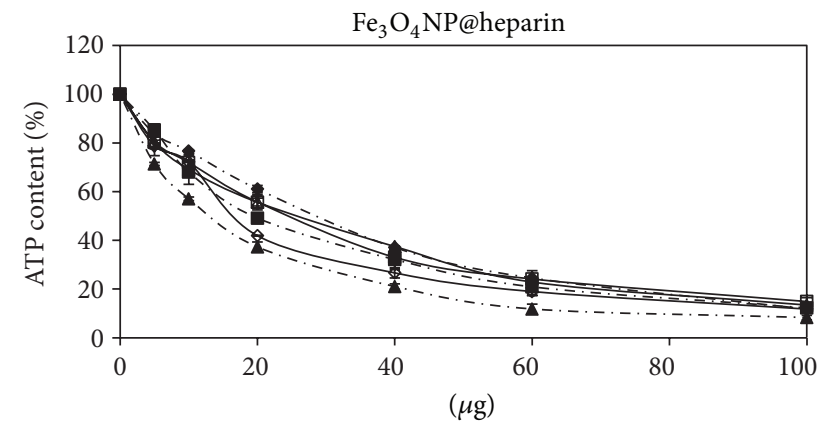

$\rightarrow 30^{\prime}$
$\square 60^{\prime}$
$\triangle 120^{\prime}$

$\rightarrow-24 \mathrm{~h}$

- $48 \mathrm{~h}$

$-\mathbf{\Delta}-72 \mathrm{~h}$

(b)

Figure 7: Percentage of ATP content, normalized to control, in SKOV-3 exposed to $\mathrm{Fe}_{3} \mathrm{O}_{4} \mathrm{NPs}_{\mathrm{a}}(\mathrm{a})$ and $\mathrm{Fe}_{3} \mathrm{O}_{4} @$ @eparin (b) for different times. 


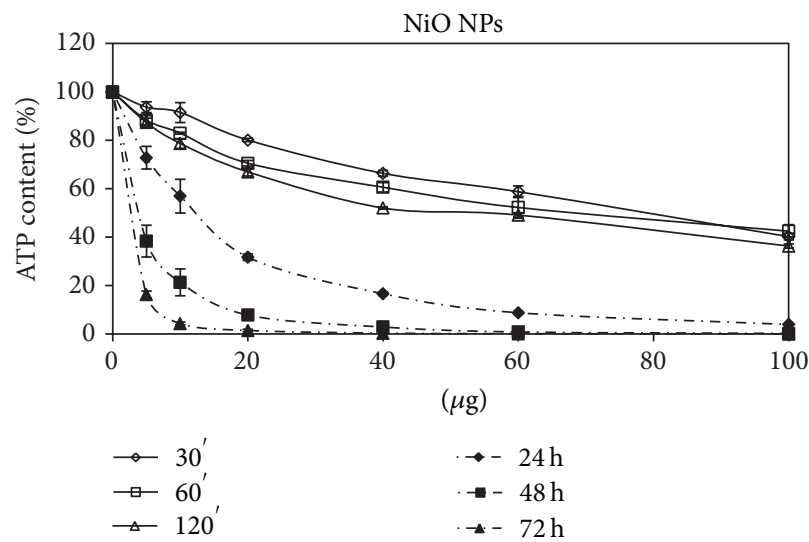

(a)

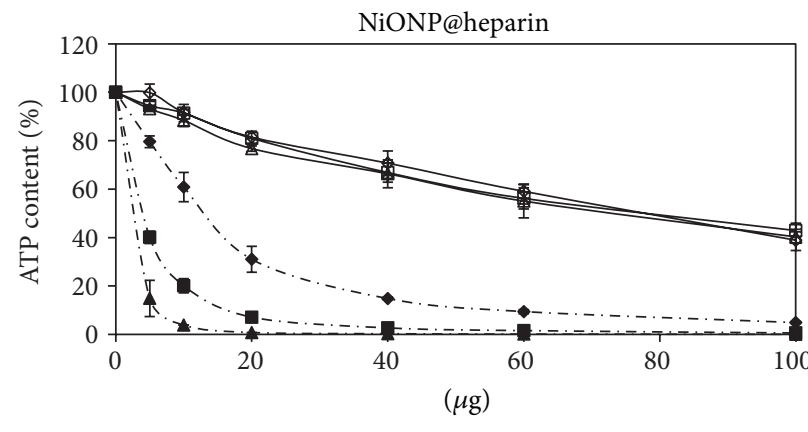

$\rightarrow 30^{\prime}$
$\square \quad 60^{\prime}$
$\square \quad 120$ $\rightarrow-24 \mathrm{~h}$

$\rightarrow-48 \mathrm{~h}$

$-72 \mathrm{~h}$

(b)

FIGURE 8: Percentage of ATP content, normalized to control, in SKOV-3 exposed to NiO NPs (a) and NiO@heparin (b) for different times.

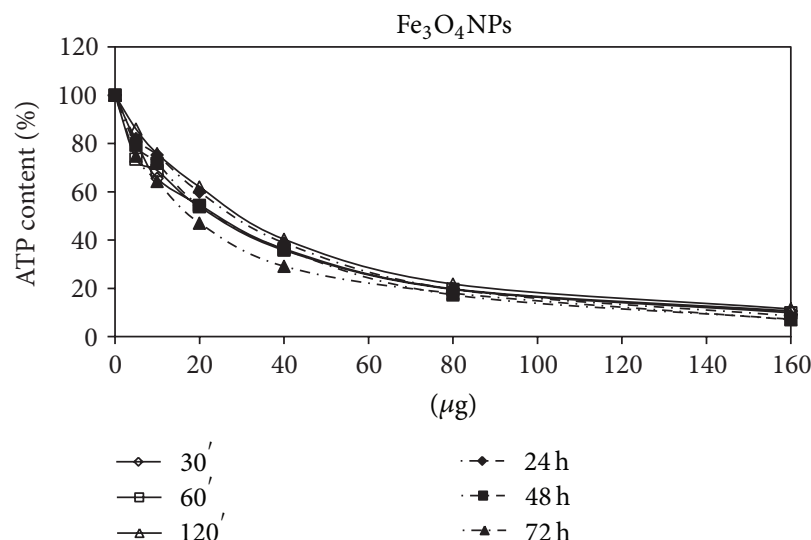

(a)

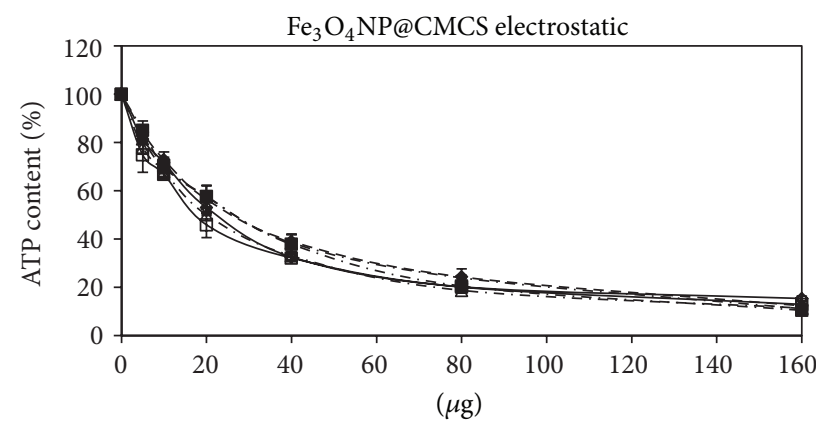

$\longrightarrow 30^{\prime}$
$\square 60^{\prime}$
$-\triangle-120^{\prime}$

$-\bullet 24 \mathrm{~h}$

$-48 \mathrm{~h}$

$\rightarrow-72 \mathrm{~h}$

(b)

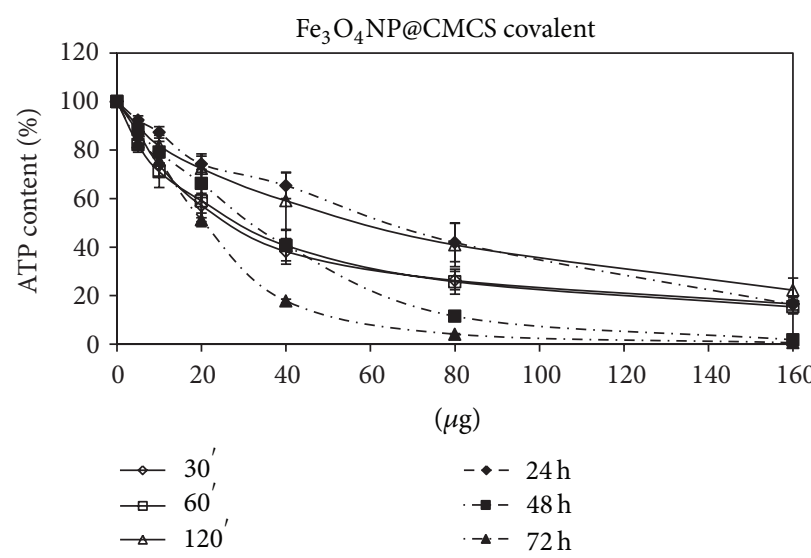

(c)

Figure 9: Percentage of ATP content, normalized to control, in SKOV-3 exposed to $\mathrm{Fe}_{3} \mathrm{O}_{4} \mathrm{NPs}$ (a), $\mathrm{Fe}_{3} \mathrm{O}_{4} @ C M C S$ electrostatic (b), and $\mathrm{Fe}_{3} \mathrm{O}_{4} @ \mathrm{CMCS}$ covalent (c) for different times. 


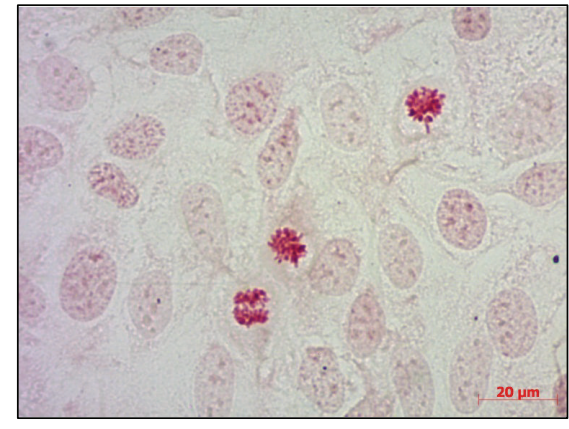

(a)

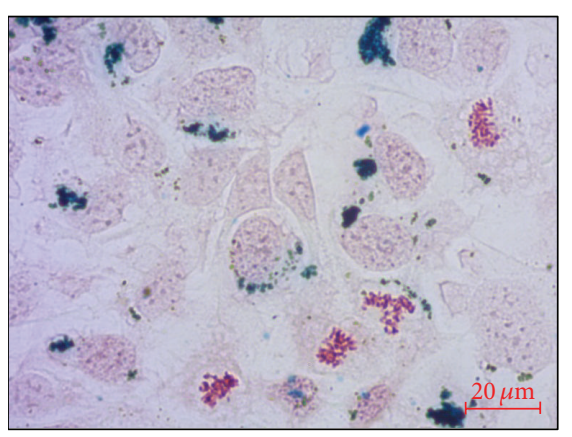

(c)

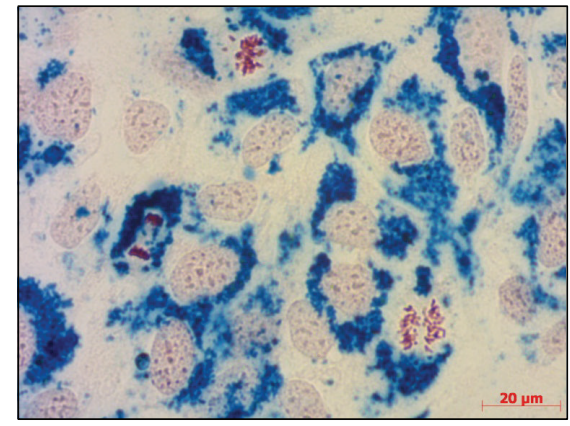

(b)

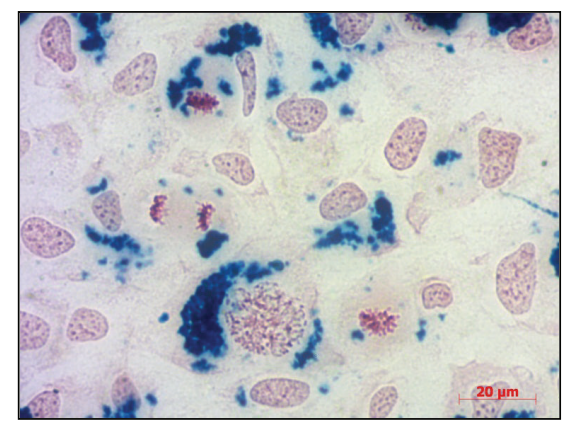

(d)

Figure 10: Uptake of SKOV-3 cells after $24 \mathrm{~h}$ of incubation with $25 \mathrm{mg} / \mathrm{mL}$ of anionic NPs. (a) Control cells; (b) $\mathrm{Fe}_{3} \mathrm{O}_{4} @$ CMCS covalent; (c) $\mathrm{Fe}_{3} \mathrm{O}_{4} @$ CMCS electrostatic; (d) $\mathrm{Fe}_{3} \mathrm{O}_{4} @$ heparin. As shown in (b, c, and d) internalized NPs did not interfere with mitosis process. Magnification: 40x.

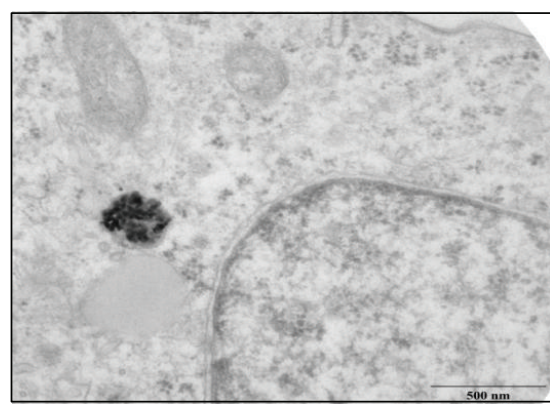

(a)

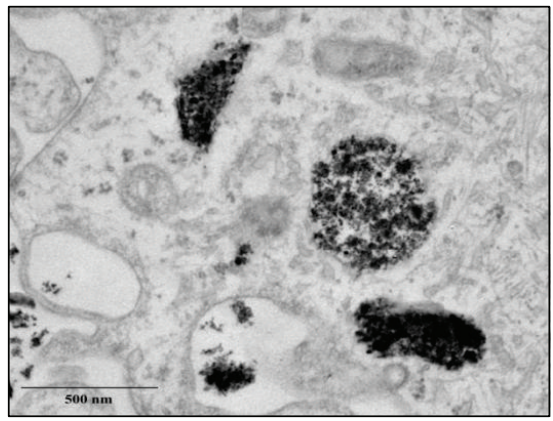

(c)

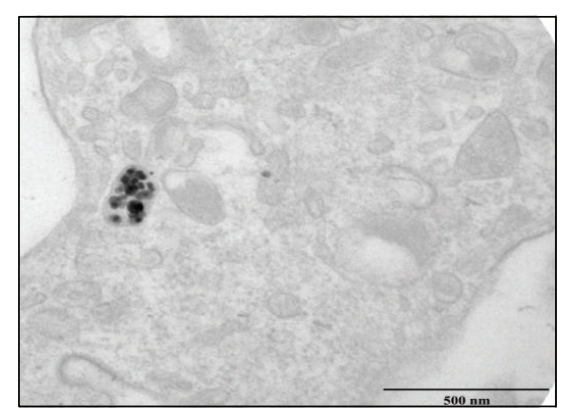

(b)

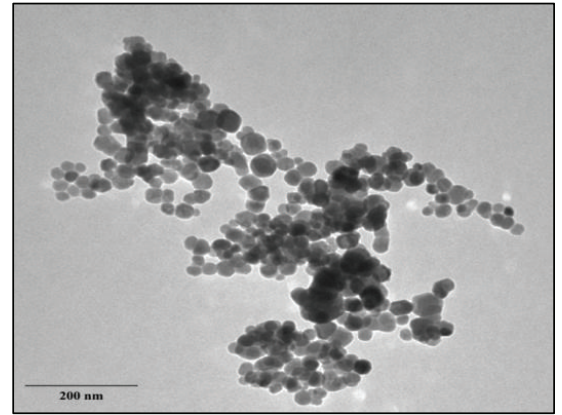

(d)

FIgURE 11: TEM pictures of SKOV-3 cells exposed to $\mathrm{Co}_{3} \mathrm{O}_{4} @$ heparin (a), $\mathrm{Fe}_{3} \mathrm{O}_{4} @$ heparin (b), and NiO@heparin (c) for 30 min. (d) A picture of $\mathrm{Fe}_{3} \mathrm{O}_{4} @$ @eparin deposited on a formvar carbon coated grid. 


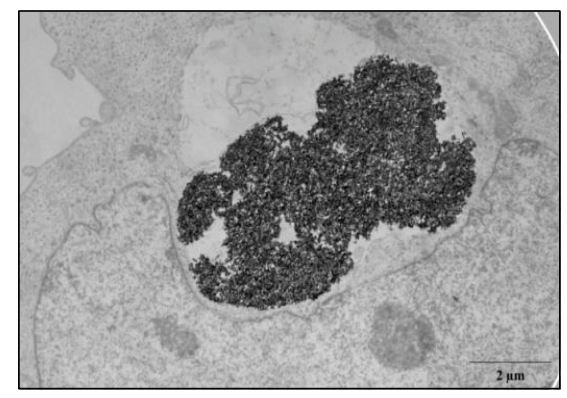

FIGURE 12: TEM picture showing a large agglomerate of $\mathrm{Co}_{3} \mathrm{O}_{4} @$ heparin which modifies the shape of a SKOV-3 nucleus. Cells were fixed after $30 \mathrm{~min}$ of exposure.

molecules, stable in physiological fluids and possibly not toxic to the body. Among the innumerable coating materials, polymers such as heparin, dextran, carboxydextran, chitosan, and polyethylene glycol are considered more advantageous to satisfy the above-mentioned characteristics [30-33].

In particular, the literature reports several applications of NPs covered with heparin, ranging from use as imaging agent to apoptosis-induced agent in cancer cell, as well as components of nanodevices [34-36]. Unfortunately, this wide number of publications does not include toxicity studies of the synthesized systems. In particular, the literature lacks data on the comparison between the toxicity of core and core@shell. To try to fill this gap, in our laboratory, we have studied the characteristics and behavior of $\mathrm{Co}_{3} \mathrm{O}_{4}, \mathrm{Fe}_{3} \mathrm{O}_{4}$, and $\mathrm{NiO}$ NPs covered with heparin.

From our experiments resulted that the coating had significantly increased the colloid stability and hydrophilic property of metal NPs. In fact, the systems NP@heparin did not agglomerated thanks to the presence of negatively charged groups around the metallic core. The experiments on cytotoxicity, performed on SKOV-3 cells, have shown that heparin itself was not toxic within the range of the examined concentrations (see Figure 5(a)). Furthermore, as expected, $\mathrm{Fe}_{3} \mathrm{O}_{4} @$ heparin was the less toxic system, while NiO@heparin was the most toxic one. Contrary to what one would expect, NP@heparin had not been found less toxic compared to the naked NPs for all the examined metals (see Figures 6, 7, and 8). Depletion of ATP content, observed in these experiments, could be due to the massive internalization of NP@heparin by the cells, phenomenon substantiated by Prussian blue staining for iron detection. Nevertheless, at the concentrations used in these experiments, internalized $\mathrm{Fe}_{3} \mathrm{O}_{4} @$ heparin did not arrest mitosis process and nanoparticles were shared between the daughter cells. Further analysis by TEM have demonstrated that NP@heparin were already present inside the cell after $30 \mathrm{~min}$ of exposure (Figures 11(a), 11(b), and 11(c)). In this work, we have not investigated the mechanisms of internalization even though, as shown in Figures 11(a), 11(b), and 11(c) and as reported by the literature [37-39], endocytosis is certainly a possible way. Notwithstanding in our previous work we had observed the presence of NPs also in the mitochondria and in the nuclei [40], in these experiments NPs were confined

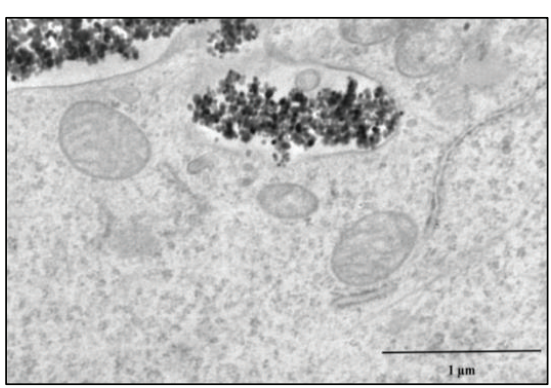

(a)

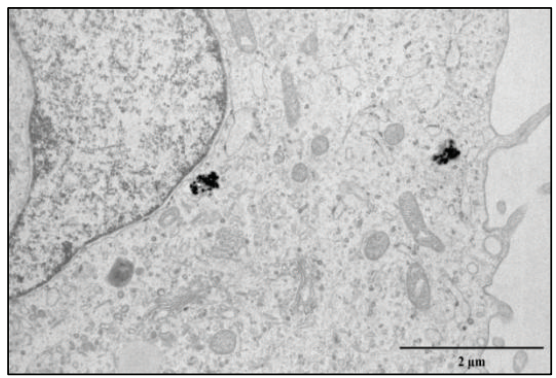

(b)

FIGURE 13: TEM pictures of SKOV-3 cells exposed for $30 \mathrm{~min}$ to $\mathrm{Fe}_{3} \mathrm{O}_{4} @ \mathrm{CMCS}$ electrostatic (a) and covalent (b).

only in cytoplasmic vesicles, even though, sometimes, the vesicle size was so enormous to modify nuclear shape and/or cause mechanical damages to the cell (see Figure 12). When the endocitotic vesicles had sizes that did not justify the mechanical damage, we could assume that cell toxicity could be due to the release of metal ions by the NP system; this hypothesis was supported by the data of cell viability in which $\mathrm{Fe}_{3} \mathrm{O}_{4} \mathrm{NPs}$ resulted the least toxic metal.

Chitosan, but even better CMCS, preferred because the carboxymethylation increases the chitosan solubility in physiological fluids, is widely studied for theranostic applications $[41,42]$. Despite the Prussian blue staining indicated that $\mathrm{Fe}_{3} \mathrm{O}_{4} @$ chitosan uptake was less efficient compared to that of $\mathrm{Fe}_{3} \mathrm{O}_{4} @$ @eparin, TEM analysis showed that no differences were noticeable between the two NP systems. Furthermore, as previously reported for heparin, the presence of negative charges on NP surface enhances interactions with the cell membrane facilitating cellular uptake $[6,38]$. Thanks to its biocompatibility and the presence of active functional groups (amino, carboxyl, and hydroxyl), CMCS is a valid instrument to design novel biocompatible materials with tailored chemical and biophysical properties [43-46]. Despite the wide use of CMCS little or nothing is known about its behavior when it is associated with metal NPs. This lack of data suggested us to evaluate the properties and the potential toxicity of the system $\mathrm{Fe}_{3} \mathrm{O}_{4} @ \mathrm{CMCS}$ itself and compared to the naked $\mathrm{Fe}_{3} \mathrm{O}_{4} \mathrm{NPs}$. For our studies, we have set up two different systems: $\mathrm{Fe}_{3} \mathrm{O}_{4} @ \mathrm{CMCS}$-electrostatic bound and $\mathrm{Fe}_{3} \mathrm{O}_{4} @ \mathrm{CMCS}$-covalent bound. The interest in coating $\mathrm{Fe}_{3} \mathrm{O}_{4}$ NPs by covalent bond resided in an attempt to get a system characterized by a more stable shell in hydrophilic fluids. 
Our studies on cell viability confirmed the biocompatibility of free CMCS at the tested conditions. When cells are exposed to $\mathrm{Fe}_{3} \mathrm{O}_{4} @ C M C S$ electrostatic, viability decreases with the same trend of $\mathrm{Fe}_{3} \mathrm{O}_{4} \mathrm{NPs}$ treatment (Figures 9(a) and 9(b)). The higher toxicity observed for $\mathrm{Fe}_{3} \mathrm{O}_{4} @$ CMCScovalent bond (Figure 9(c)) suggested that the method of preparation of the NPs could influence the cellular response.

Also in this case, uptake by SKOV-3 cells was relevant showing massive internalization already after $30 \mathrm{~min}$ with NPs stored in cytoplasmic vesicles (Figure 13) with no detectable difference between NP@heparin and $\mathrm{Fe}_{3} \mathrm{O}_{4} @ \mathrm{CMCS}$.

Our results have confirmed the data present in the literature about the biocompatibility of heparin and CMCS and their capability to get stable suspensions in hydrophilic fluids when conjugated to metal NPs, but not the ability to reduce the cytotoxicity of metal NPs coated with these polymers. Nevertheless, it is difficult to compare data derived from different experimental conditions such as different concentration ranges rather than diverse cell types which can give diverse responses to the same treatment [2, 47]. Moreover, the published data are often related to the whole system prepared and not to the single component, as we did, then the comparison is very difficult if not impossible.

In conclusion, the reactive groups, present on the surface of core@shell systems that we have synthesized, provide the opportunity for further functionalization so that a variety of biomolecules may be immobilized to enhance specific cell recognition for their use in targeting studies. Moreover, as regards $\mathrm{Fe}_{3} \mathrm{O}_{4} \mathrm{NPs}$, even though the coating does not reduce their toxicity, the amount of NPs present in the systems is usually so low to render their toxicity negligible. Furthermore, due to their magnetic properties, $\mathrm{Fe}_{3} \mathrm{O}_{4} \mathrm{NPs}$ can be directed to the site of interest thanks to an external magnet. From this point of view, they could be promising tools as drug carrier for diagnosis and therapy.

\section{Conflict of Interests}

No conflict of interests is present. The authors have no financial involvement or interest with any organization or company about subjects or materials discussed in the paper.

\section{Acknowledgments}

A. Bava was supported by Consorzio Interuniversitario Biotecnologie and by Associazione Amici dell'Università grants.

\section{References}

[1] A. G. Cattaneo, R. Gornati, E. Sabbioni et al., "Nanotechnology and human health: risks and benefits," Journal of Applied Toxicology, vol. 30, no. 8, pp. 730-744, 2010.

[2] H. Eidi, O. Joubert, G. Attik et al., "Cytotoxicity assessment of heparin nanoparticles in NR8383 macrophages," International Journal of Pharmaceutics, vol. 396, no. 1-2, pp. 156-165, 2010.

[3] M. M. Kemp and R. J. Linhardt, "Heparin-based nanoparticles," Wiley Interdisciplinary Reviews: Nanomedicine and Nanobiotechnology, vol. 2, no. 1, pp. 77-87, 2010.
[4] V. K. Mourya, N. N. Inamdar, and A. Tiwari, "Carboxymethyl chitosan and its applications," Advanced Materials Letters, vol. 1, no. 1, pp. 11-33, 2010.

[5] R. Riva, H. Ragelle, A. des Rieux, N. Duhem, C. Jérôme, and V. Préat, "Chitosan and chitosan derivatives in drug delivery and tissue engineering," Advances in Polymer Science, vol. 244, pp. 19-44, 2011.

[6] A. Zhu, L. Yuan, and T. Liao, "Suspension of $\mathrm{Fe}_{3} \mathrm{O}_{4}$ nanoparticles stabilized by chitosan and o-carboxymethylchitosan," International Journal of Pharmaceutics, vol. 350, no. 1-2, pp. 361-368, 2008.

[7] H. Y. Hwang, I. S. Kim, I. C. Kwon, and Y. H. Kim, "Tumor targetability and antitumor effect of docetaxel-loaded hydrophobically modified glycol chitosan nanoparticles," Journal of Controlled Release, vol. 128, no. 1, pp. 23-31, 2008.

[8] R. Dinarvand, N. Sepehri, S. Manoochehri, H. Rouhani, and F. Atyabi, "Polylactide-co-glycolide nanoparticles for controlled delivery of anticancer agents," International Journal of Nanomedicine, vol. 6, pp. 877-895, 2011.

[9] C. E. Mora-Huertas, H. Fessi, and A. Elaissari, "Polymerbased nanocapsules for drug delivery," International Journal of Pharmaceutics, vol. 385, no. 1-2, pp. 113-142, 2010.

[10] A. Bava, R. Gornati, F. Cappellini, L. Caldinelli, L. Pollegioni, and G. Bernardini, "D-amino acid oxidase-nanoparticle system: a potential novel approach for cancer enzymatic therapy," Nanomedicine, 2013.

[11] A. Nel, T. Xia, L. Mädler, and N. Li, “Toxic potential of materials at the nanolevel," Science, vol. 311, no. 5761, pp. 622-627, 2006.

[12] S. Singh and H. S. Nalwa, "Nanotechnology and health safety - Toxicity and risk assessments of nanostructured materials on human health," Journal of Nanoscience and Nanotechnology, vol. 7, no. 9, pp. 3048-3070, 2007.

[13] E. Papis, R. Gornati, J. Ponti, M. Prati, E. Sabbioni, and G. Bernardini, "Gene expression in nanotoxicology: a search for biomarkers of exposure to cobalt particles and ions," Nanotoxicology, vol. 1, no. 3, pp. 198-203, 2007.

[14] E. Papis, R. Gornati, M. Prati, J. Ponti, E. Sabbioni, and G. Bernardini, "Gene expression in nanotoxicology research: analysis by differential display in BALB3T3 fibroblasts exposed to cobalt particles and ions," Toxicology Letters, vol. 170, no. 3, pp. 185-192, 2007.

[15] M. Di Gioacchino, N. Verna, L. Di Giampaolo et al., "Immunotoxicity and sensitizing capacity of metal compounds depend on speciation," International Journal of Immunopathology and Pharmacology, vol. 20, no. 2, pp. 15-22, 2007.

[16] A. Munoz and M. Costa, "Elucidating the mechanisms of nickel compound uptake: a review of particulate and nano-nickel endocytosis and toxicity," Toxicology and Applied Pharmacology, vol. 260, pp. 1-16, 2012.

[17] A. G. . Cattaneo, R. Gornati, M. Chiriva-Internati, and G. Bernardini, "Ecotoxicology of nanomaterials: the role of invertebrate testing," Invertebrate Survival Journal, vol. 6, pp. 78-97, 2009.

[18] Y. Xu, Z. Wen, and Z. Xu, "Chitosan nanoparticles inhibit the growth of human hepatocellular carcinoma xenografts through an antiangiogenic mechanism," Anticancer Research, vol. 29, no. 12, pp. 5103-5109, 2009.

[19] P. Poizot, S. Laruelle, S. Grugeon, L. Dupont, and J. M. Tarascon, "Nano-sized transition-metal oxides as negative-electrode materials for lithium-ion batteries," Nature, vol. 407, no. 6803, pp. 496-499, 2000. 
[20] L. D. Pachón and G. Rothenberg, "Transition-metal nanoparticles: synthesis, stability and the leaching issue," Applied Organometallic Chemistry, vol. 22, no. 6, pp. 288-299, 2008.

[21] M. Moreno-Mañas and R. Pleixats, "Formation of carboncarbon bonds under catalysis by transition-metal nanoparticles," Accounts of Chemical Research, vol. 36, no. 8, pp. 638-643, 2003.

[22] S. Rafique, M. Idrees, A. Nasim, H. Akbar, and A. Athar, "Transition metal complexes as potential therapeutic agents," Biotechnology and Molecular Biology Reviews, vol. 5, no. 2, pp. 38-45, 2010.

[23] A. Zhu, M. B. Chan-Park, S. Dai, and L. Li, “The aggregation behavior of O-carboxymethylchitosan in dilute aqueous solution," Colloids and Surfaces B, vol. 43, no. 3-4, pp. 143-149, 2005.

[24] Y. Y. Liang and L. M. Zhang, "Bioconjugation of papain on superparamagnetic nanoparticles decorated with carboxymethylated chitosan," Biomacromolecules, vol. 8, no. 5, pp. 14801486, 2007.

[25] D. R. Kester, I. W. Duedall, D. N. Connors, and R. M. Pytkowicz, "Preparation of artificial sea water," Limnology and Oceanography, vol. 12, no. 1, pp. 176-179, 1967.

[26] R. Bhattacharya and P. Mukherjee, "Biological properties of "naked" metal nanoparticles," Advanced Drug Delivery Reviews, vol. 60, no. 11, pp. 1289-1306, 2008.

[27] J. Conde, G. Doria, and P. Baptista, "Noble metal nanoparticles applications in cancer," Journal of Drug Delivery, vol. 2012, Article ID 751075, 12 pages, 2012.

[28] J. L. Martinez-Hurtado, "Metallic nanoparticle block copolymer vesicles with enhanced optical properties," Nanomaterials, vol. 1, pp. 20-30, 2011.

[29] P. Tartaj, M. Del Puerto Morales, S. Veintemillas-Verdaguer, T. González-Carreño, and C. J. Serna, "The preparation of magnetic nanoparticles for applications in biomedicine," Journal of Physics D, vol. 36, no. 13, pp. R182-R197, 2003.

[30] M. M. Kemp, A. Kumar, S. Mousa et al., "Synthesis of gold and silver nanoparticles stabilized with glycosaminoglycans having distinctive biological activities," Biomacromolecules, vol. 10, no. 3, pp. 589-595, 2009.

[31] H. Khurshid, S. H. Kim, M. J. Bonder et al., "Development of heparin-coated magnetic nanoparticles for targeted drug delivery applications," Journal of Applied Physics, vol. 105, no. 7, Article ID 07B308, 3 pages, 2009.

[32] C. Sun, J. S. H. Lee, and M. Zhang, "Magnetic nanoparticles in MR imaging and drug delivery," Advanced Drug Delivery Reviews, vol. 60, no. 11, pp. 1252-1265, 2008.

[33] O. Veiseh, J. W. Gunn, and M. Zhang, "Design and fabrication of magnetic nanoparticles for targeted drug delivery and imaging," Advanced Drug Delivery Reviews, vol. 62, no. 3, pp. 284-304, 2010.

[34] D. Y. Lee, "Highly effective T2 MR contrast agent based on heparinized superparamagnetic iron oxide nanoparticles," Macromolecular Research, vol. 19, no. 8, pp. 843-847, 2011.

[35] K. Lee, H. Lee, K. H. Bae, and T. G. Park, "Heparin immobilized gold nanoparticles for targeted detection and apoptotic death of metastatic cancer cells," Biomaterials, vol. 31, no. 25, pp. 65306536, 2010.

[36] K. A. Min, F. Yu, V. C. Yang, X. Zhang, and G. R. Rosania, "Transcellular transport of heparin-coated magnetic iron oxide nanoparticles (Hep-MION) under the influence of an applied magnetic field," Pharmaceutics, vol. 2, no. 2, pp. 119-135, 2010.
[37] A. Villanueva, M. Cãete, A. G. Roca et al., "The influence of surface functionalization on the enhanced internalization of magnetic nanoparticles in cancer cells," Nanotechnology, vol. 20, no. 11, Article ID 115103, 9 pages, 2009.

[38] E. Sabbioni, S. Fortaner, M. Farina et al., "Interaction with culture medium components, cellular uptake and intracellular distribution of cobalt nanoparticles, microparticles and ions in Balb/3T3 mouse fibroblasts," Nanotoxicology, 2012.

[39] C. Wilhelm and F. Gazeau, "Universal cell labelling with anionic magnetic nanoparticles," Biomaterials, vol. 29, no. 22, pp. 31613174, 2008.

[40] E. Papis, F. Rossi, M. Raspanti et al., "Engineered cobalt oxide nanoparticles readily enter cells," Toxicology Letters, vol. 189, no. 3, pp. 253-259, 2009.

[41] H. Arami, Z. Stephen, O. Veiseh, and M. Zhang, "Chitosancoated iron oxide nanoparticles for molecular imaging and drug delivery," Advances in Polymer Science, vol. 243, pp. 63-184, 2011.

[42] X. G. Chen and H. J. Park, "Chemical characteristics of $O$ carboxymethyl chitosans related to the preparation conditions," Carbohydrate Polymers, vol. 53, no. 4, pp. 355-359, 2003.

[43] A. P. Zhu, N. Fang, M. B. Chan-Park, and V. Chan, "Interaction between O-carboxymethylchitosan and dipalmitoyl-snglycero-3- phosphocholine bilayer," Biomaterials, vol. 26, no. 34, pp. 6873-6879, 2005.

[44] P. Agrawal, G. J. Strijkers, and K. Nicolay, "Chitosan-based systems for molecular imaging," Advanced Drug Delivery Reviews, vol. 62, no. 1, pp. 42-58, 2010.

[45] D. Bhattacharya, M. Das, D. Mishra et al., "Folate receptor targeted, carboxymethyl chitosan functionalized iron oxide nanoparticles: a novel ultradispersed nanoconjugates for bimodal imaging," Nanoscale, vol. 3, no. 4, pp. 1653-1662, 2011.

[46] T. T. Trang Mai, P. T. Ha, H. N. Pham et al., "Chitosan and $\mathrm{O}$-carboxymethylchitosan modified $\mathrm{Fe}_{3} \mathrm{O}_{4}$ for hyperthermic treatment," Advances in Natural Sciences: Nanoscience and Nanotechnology, vol. 3, Article ID 015006, 5 pages, 2012.

[47] C. F. Jones and D. W. Grainger, "In vitro assessments of nanomaterial toxicity," Advanced Drug Delivery Reviews, vol. 61, no. 6, pp. 438-456, 2009. 

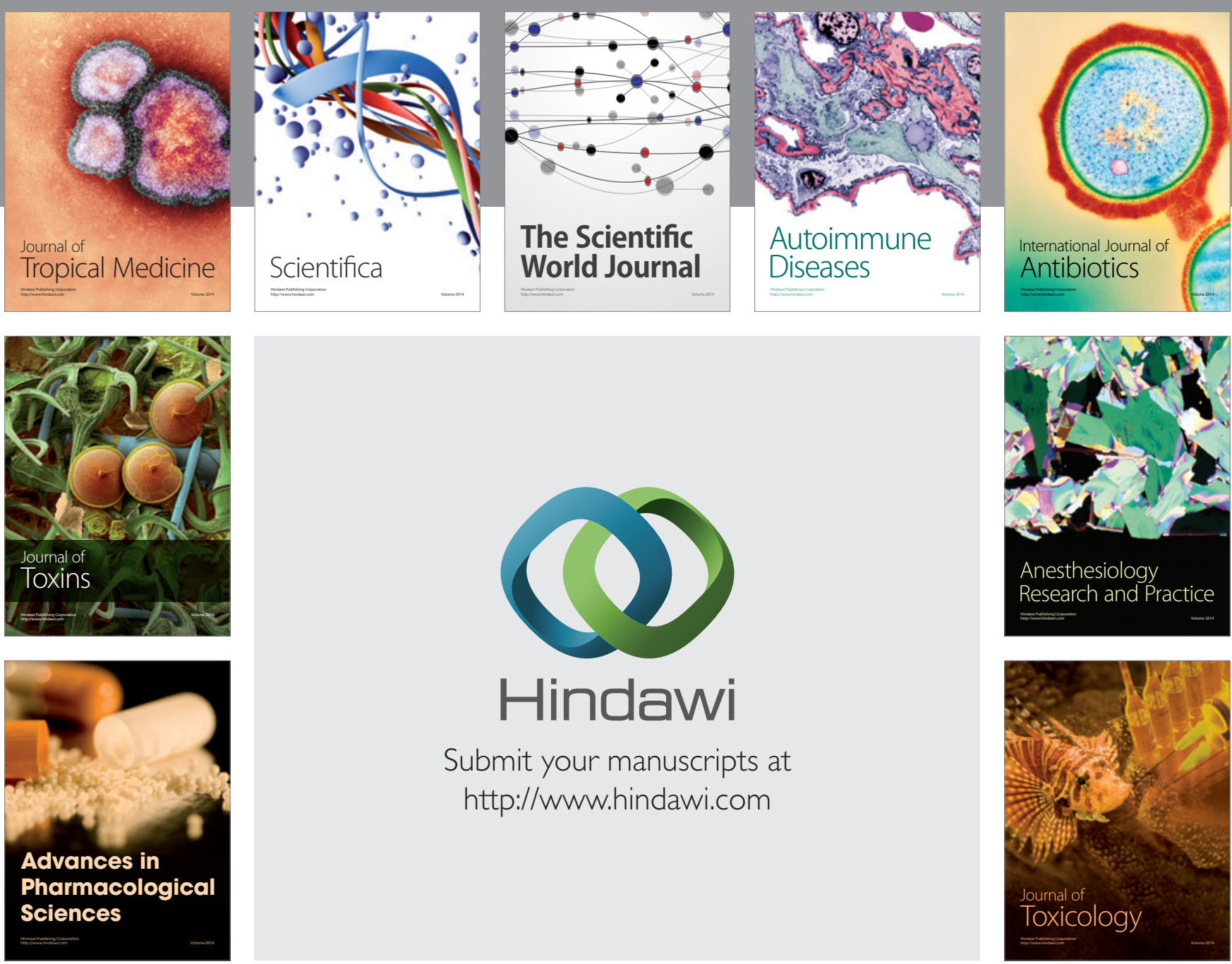

\section{Hindawi}

Submit your manuscripts at

http://www.hindawi.com
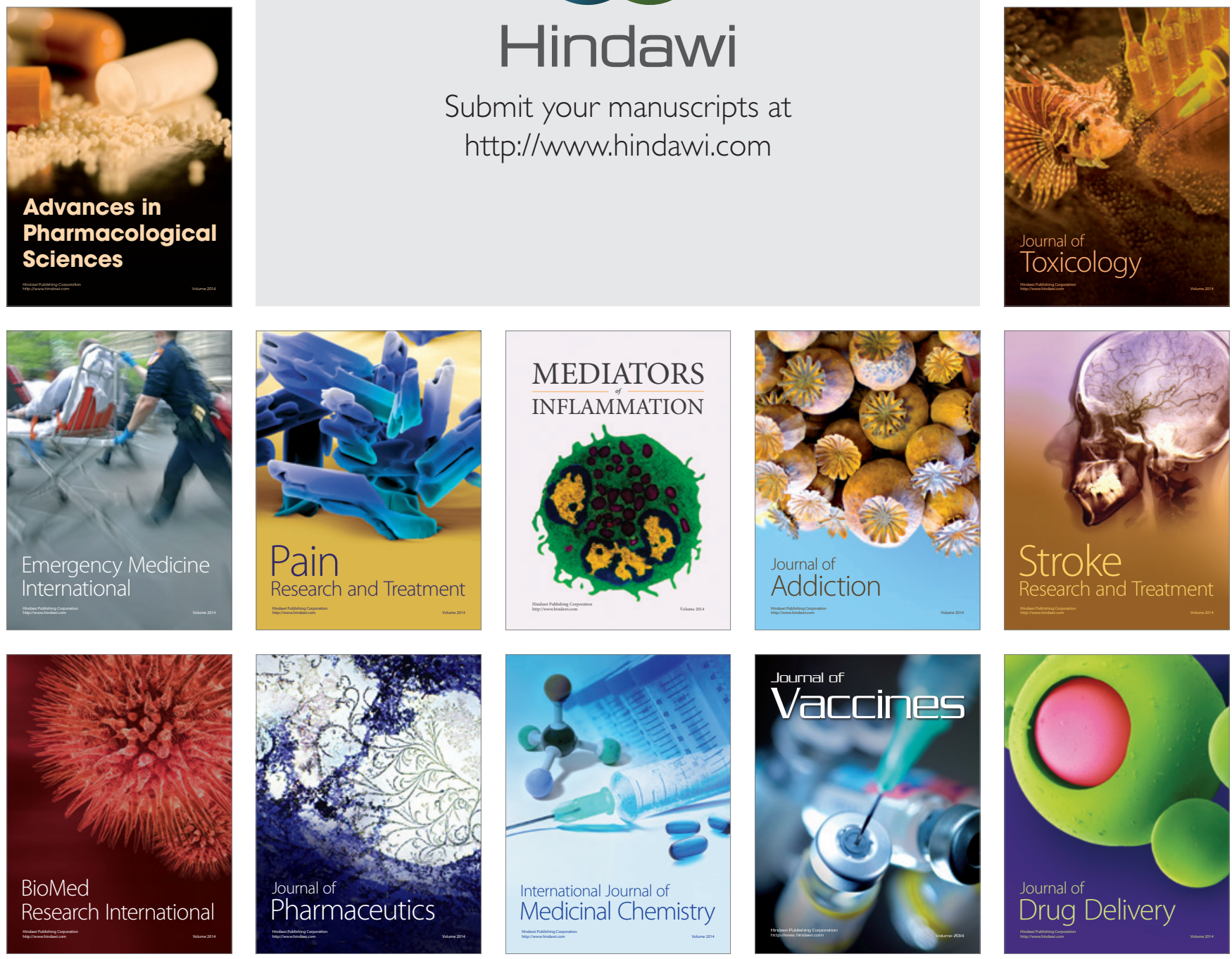